\title{
Late Quaternary Caspian: Sea-Levels, Environments and Human Settlement
}

\author{
P.M. Dolukhanov ${ }^{*}, 1$, A.L. Chepalyga ${ }^{2}$, V.K. Shkatova ${ }^{3}$ and N.V. Lavrentiev ${ }^{2}$ \\ ${ }^{1}$ School of Historical Studies, Newcastle University, UK \\ ${ }^{2}$ Institute of Geography, Russian Academy of Sciences, Moscow, Russia \\ ${ }^{3}$ A.P. Karpinsky Russian Geological Research Institute (VSEGEI), St. Petersburg, Russia
}

\begin{abstract}
This paper is focused on the discussion of the exact age, and environmental setting of the 'Khvalynian' Transgression of the Caspian Sea with the use of novel radiometric, isotopic evidence and GIS-linked modelling. Based on this evidence the Khvalynian transgression is viewed as coeval with the warm Late Glacial episodes in the higher latitudes, reaching its peak at 13.6 - $11.8 \mathrm{ka}$. During that period the Caspian Sea was connected with the Caspian Sea via the 'Manych-Kerch-Spillway' north of the Caucasus Mountains. We also suggest a younger age for Mousterian sites in the Caspian basin, which are usually associated with the populations of Neanderthal humans. The initial emergence of Mousterian industries in this area was broadly contemporaneous with MOI 3 that included the LGM (25-18 ka). Their expansion was largely coeval with the Khvalynian transgression.
\end{abstract}

Keywords: Caspian Sea, Late Pleistocene, Khvalynian Transgression, Mousterian, Neanderthals.

\section{INTRODUCTION}

The Caspian Sea is the world's largest lake of inner drainage, with no outlet to the ocean (Fig. 1). The sea extends over $1000 \mathrm{~km}$ from the north to the south, and consists of three basins, which differ by their depth and geologic histories: the northern $\left(80,000 \mathrm{~km}^{2}\right.$, an average depth of 5-6 m and a maximum depth of $15-20 \mathrm{~m})$; the middle $(138,000$ $\mathrm{km}^{2}$, an average depth of $175 \mathrm{~m}$ and a maximum depth of $788 \mathrm{~m})$, and the southern one $\left(168,000 \mathrm{~km}^{2}\right.$, an average depth of $325 \mathrm{~m}$ and a maximum depth of $1025 \mathrm{~m}$ ). The Caspian drainage basin covers more than 3 million sq $\mathrm{km}$, and includes the Volga, Europe's largest river, which contributes more than $80 \%$ of the total river inflow, as well as several smaller rivers. The salinity rises in the southern direction, from almost freshwater in the north, to $12.5-13.5 \mathrm{psu}$ in the south.

The Caspian basin extends over several climatic zones, of which only the southern and south-western coastal areas are humid, all other areas having a pronounced arid climate. The western, northern and north-eastern areas where rainfalls fall mostly in winter, sustain a semi-desert vegetation belonging to the 'Kazakh-Dsungarian' province. The southern areas with summer rainfall and cold winters have a rich 'IranoTouranian'vegetation.

The peculiarity of the Caspian Sea consists in repeatedly occurring oscillations of its level. Presently the sea-level stands at $27 \mathrm{~m}$ below the ocean's level. Only 30 years ago, in 1977, its level was $2.5 \mathrm{~m}$ lower, reaching an all-time low of $29.01 \mathrm{~m}$. Before that, since the 1930s, the Caspian sea-level continuously dropped to the total value of more than $3 \mathrm{~m}$. In the course of late $19^{\text {th }}$ century (when regular observations

*Address correspondence to this author at the School of Historical Studies, Newcastle University, UK; E-mail: pavel.dolukhanov@newcastle.ac.uk started) and in early $20^{\text {th }}$ century the Caspian level remained at $25.5-26.0 \mathrm{~m}$ below the ocean, with a downward trend. Much greater changes of the Caspian sea-level are recorded in its geologic past.

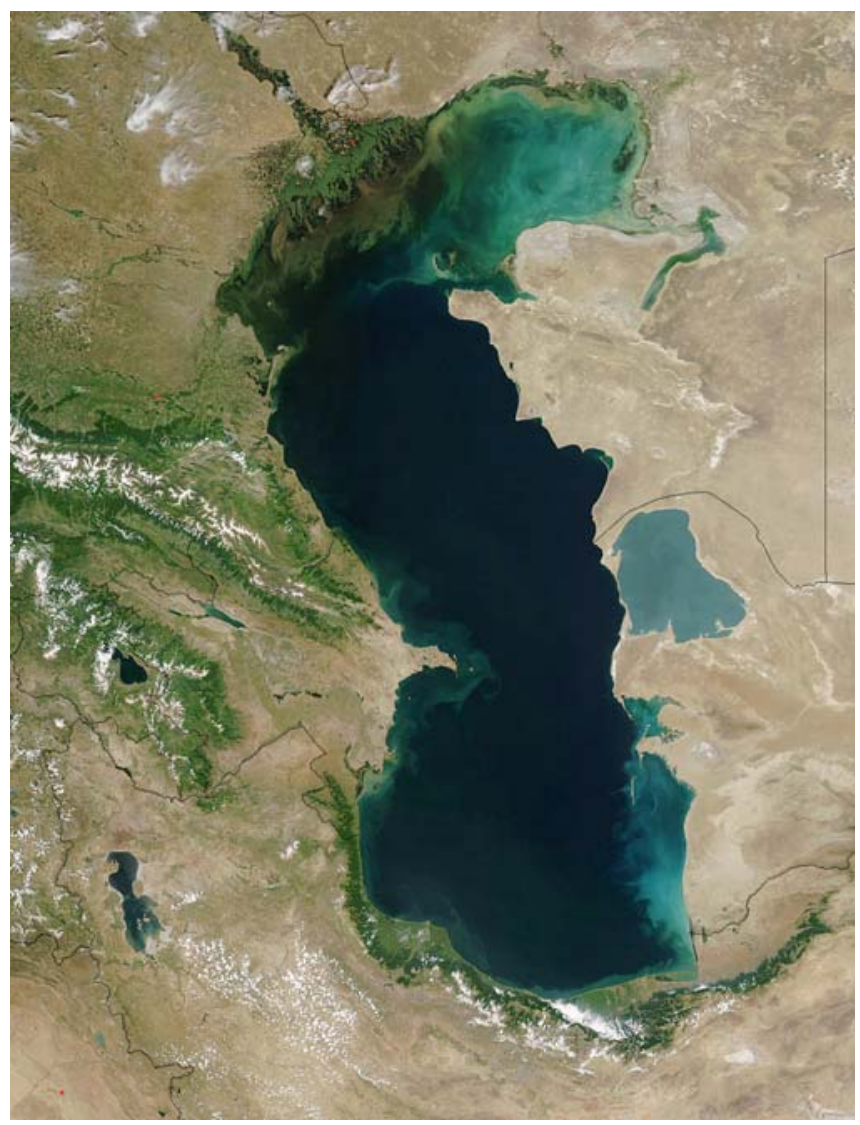

Fig. (1). The Caspian Sea. Source: NASA Goddard Space Flight Centre. 
One of the most dramatic phenomenon of the Caspian recent geological history was the so-called 'Khvalynian' Transgression, which scale had few precedents on geological records. The present paper is aimed at discussing several related issues which include:

1. The nature, age and environmental setting of the Khavynian transgression;

2. Its connection with the Black Sea;

3. Its impact on the movements and livelihood of early humans.

\section{THE BACKGROUND}

The Caspian Sea lays in the collision zone of Eurasian and Afro-Arabian tectonic plates [1]. Jointly with the Black, and Aral Seas, the Caspian Sea is a relic of the huge Tethys basin, which attained its maximum extension in Jurassic, ca. 150 million years (Ma) ago. During the Oligocene (30-10 $\mathrm{Ma}$ ) the Afro-Arabian plate moving to the north formed a zone of subduction, and separated the Tethys' northern periphery, the Parathesys. During the Middle Miocene (15-14 Ma) the large-scale mountain-building split up the Parathesys into several minor basins, the South Caspian basin being one of them. At a later stage, the subsidence in the northern Caucasus and the adjacent Scythian-Turanian platform formed the Middle Caspian basin. Still later the Caspian basin jointed its northern extension, which had been part of a huge marine basin that had existed since the Devonian period. By the end of Miocene, ca 5.3 Ma, the advance of the Arabian Plate further to the north caused the massive uplift of the Caucasus which eventually separated the Caspian from the Black Sea. In Early Pliocene (5-3 Ma) the Northern and Middle Caspian basins became dry land, and the PalaeoVolga carried its water directly into the South Caspian basin. The remaining marine basin was filled in with sands and clays and formed the main Caspian hydrocarbon reservoir.

The first major Cainozoic transgression of the Caspian Sea, the Akchagylian, started at ca 3.3 Ma. During its latest stage, which lasted until ca 1.2 Ma, the Caspian waters submerged all low-lying areas of the Caucasus, Turkmenistan and the greater part of the Volga catchment. The next major Caspian Sea transgression, the Apsheronian, began at ca 1.6 $\mathrm{Ma}$ and lasted until $0.96 \mathrm{Ma}$ [2]. Its sediments, which show a reversed magnetization [3], are found at $300 \mathrm{~m}$ absolute height (in meters above the ocean level). At that time, the Caspian became connected with the Black Sea via a strait in the Kuma-Manych depression, north of the Caucasus Mts. All subsequent Caspian deposits show the normal magnetic polarity (except minor excursions), meaning that they correspond to Brunhes magnetic epoch $(<780 \mathrm{ka})$ [4]. During the course of the Baku transgression (500-400 ka) a connection with the Black Sea was re-established through the 'KumoManych' strait, and a large basin fed by the Caspian waters emerged in the place of the Azov Sea and the lower Don River.

The next episodes in the Caspian Sea history that occurred during the Late Pleistocene and Holocene were roughly coeval with the marine oxygen isotope (MIS) stages 5 -1. Two major Caspian Sea transgressions are acknowledgeable at that time. The Khazarian, the earlier one, had been first identified in the early $20^{\text {th }}$ century by Andrusov and Pravoslavlev [5, 6] and later substantiated by Fedorov [7], predominantly on the mollusc evidence. The Khazarian terraces on the Caucasian coast are encountered at the altitudes ranging from 170 to $80 \mathrm{~m}$. The exact age of these deposits, the absolute height reached by these transgressions, the hydrological regime and their general environments remain hotly debated issues.

The Khvalynian, transgression first identified by Andrusov [5] has been studied by several generations of Russian geologists [7-12]. The Khvalynian deposits usually overlie the 'Atelian' loams that had been formed during the regression that followed the Khazarian transgression. In its course considerable shelf areas in the Caspian Sea northern part were exposed and the brackish water mollusc assemblages with Didacna trigonoides became dominant [13].

Mainly based on geomorphic criteria, two major stages of the Khvalynian transgression were recognised. The coastal landforms and corresponding deposits situated above $0 \mathrm{~m}$ absolute height are classified as the Early Khvalynian, whereas those between 0 and $-17 \mathrm{~m}$ absolute height are viewed as the Late Khvalynian [13]. Presently nine Khvalynian terraces are identified on the Caspian coasts: $+48 \mathrm{~m}$, $+35 \mathrm{~m},+22 \mathrm{~m},+6 \mathrm{~m},-5 \mathrm{~m} \pm 0,-2 \mathrm{~m} ;-12 \mathrm{~m}$ and $-16 \mathrm{~m}[10,12]$.

The Khvalynian mollusc fauna consists of Caspian endemics, belonging to the Lymnocardiidae family, and typically, Didacna Eichwald genus. Presently exclusively restricted to the Caspian basin, this fauna had a wider distribution in the Azov-Black Sea during the Pleistocene, including its Karangatian stage [14]. The diagnostic fossils of Early Khavalynian mollusc assemblage include Didacna cristata Bog., D. ebersini Fed., D. zhukovi Fed., D. parallella Bog. and D. protracta Eichw [9]. These molluscs are distinctive by their small size (2-3 time smaller than the present-day varieties), and thin walls. The less varied Late Khavalynian mollusc assemblage consists predominantly of Didacna praetrigonoides Nal., D. parallella, D. protracta and, more rarely, D. subcatillus Andr. These species are of a greater size and feature a massive abundance [15] (Fig. 2).

Khvalynian deposits include various marine facies, from the psephytic coastal to fine-grained clayey ones, the "chocolate' clay found in a wide area of Lower Volga and KumoManych depressions being most common. Reaching the thickness of up to $30 \mathrm{~m}$ and formed during geologically short span of time, they consist of interbedded thin layers of clay and silt [16].

The environmental setting of the Khvalynian transgression, its detailed chronology and correlations with global climatic events remain controversial. Rychagov and Leontjev [17] based mostly on TL dates estimated the age of the Early Khvalynian transgression as $70-40 \mathrm{ka}$, and that of the Late Khvalynian as 20-10 ka. Accordingly, a suggestion was made [11] that these transgressions were broadly coeval with the Last (Valdai, Weichselian) Ice Age (isotopic stages 4-2) in the higher latitudes. An opposite point of view based on ${ }^{14} \mathrm{C}$ and U-Th dating was advanced [18], which argued for its much younger age, falling within the range of 20-7 ka BP. The ages in the order of 16-10 ka have been obtained for the samples of the transgressive phase of Early Khvalynian transgression from the sequences of the Lower Volga with the use of AMS technique [19]. 


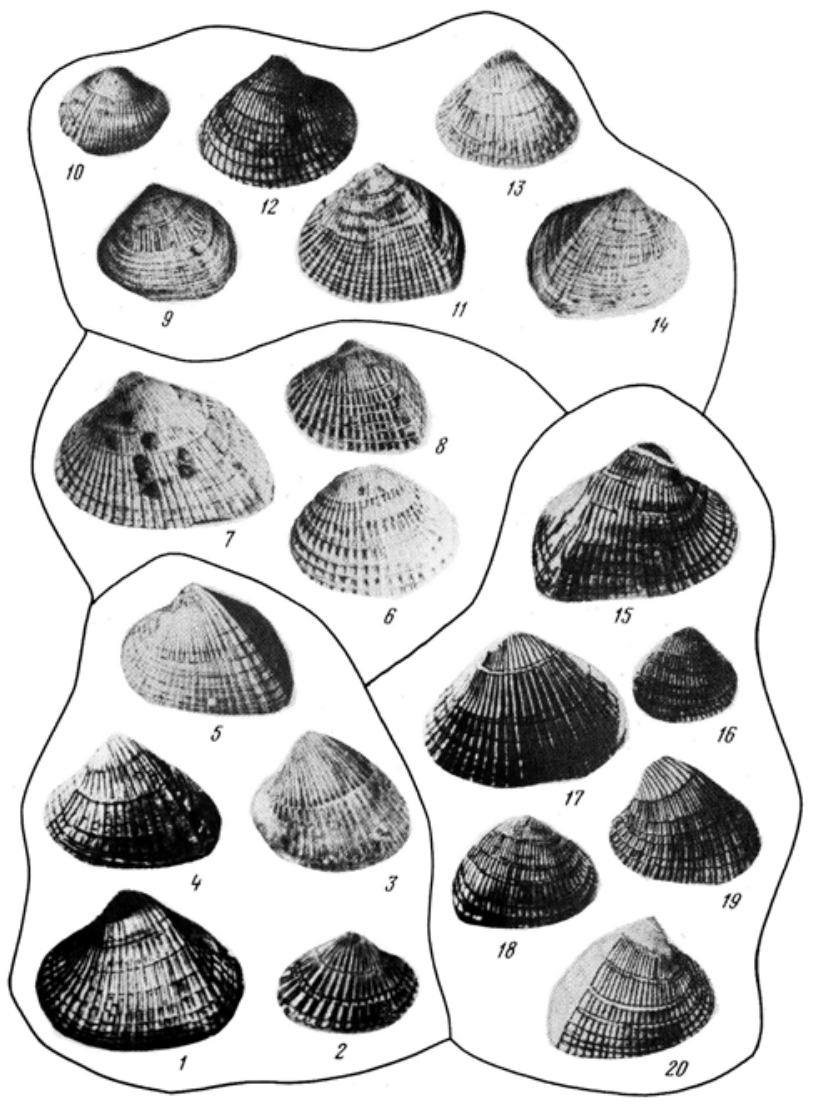

Fig. (2). Khvalynian Didacna molluscs [3]. Key: Azerbaijan: 1 Didacns praetrigonoides; 2 - D. parallela; 3 - D. ex. trigonoides; 4 - D. cristata; Dagestan: 5 - D. parallela; 6 - D. subcatillus; 7 - D. praetrigonoides; 8 - D. parallela; Northern Caspian area: 9 - D. parallela; 10 - D. trigonoides chvalynica; 11 - D. delenda; 12 - D. praetrigonoides; 13 - D. trigonoides subtrigonoides; 14 - D. protracta; Eastern Caspian area: 15 - D. crassa pallasi; 16 - D. umbonata; 17 - D. subcatillus; 18 - D. delenda; 19-20 - D. praetrigonoides. Scale: c. 1: 1.5 .

\section{MATERIALS AND METHODOLOGY}

Our field studies included the detailed geologic and geomorphologic survey conducted in several key areas of the Caspian basin, with the special reference to the lateral facies variations, the use of GIS technology for the correlation of the coastal forms with archaeological deposits, and the sampling for radiometric and isotopic measurements.

The array of radiometric techniques was used for assessing the chronology of marine formations. Several samples were dated with the use of Th-U methods at the Geographical Research Institute, St. Petersburg University (Prof. Kh.A. Arslanov). Five samples were dated by ESR method at the Institute of Geology, Tallinn University, Estonia (Dr. V.N. Molodkov). 27 samples were measured with the use of TL method (Dr. A.I. Shlukov, Moscow University). 305 samples were studied by paleomagnetic methods (Dr. E.A. Molostovsky and Dr. V.N. Yeremin, Geological Research Institute, Saratov University).

The changes in temperature and salinity of sea water were estimated based on the combined use of oxygen isotope O18/O16) analyses, and the measurement of $\mathrm{Ca} / \mathrm{Mg}$ ratio in the aragonite extracted from Didacna shells. The samples taken from the various points of the shells enabled one to estimate the seasonal temperature changes, as the magnesium content seasonally increased with temperature rise [20]. Altogether 29 samples $(D$. surachanica, $D$. crassa nalivkini and D. protracta protracta) from the Upper Khazarian and 40 samples from the Lower and Upper Khvalynian samples were studied with the use of the latter technique. These analyses were performed by Dr. L.A. Dorofeeva, at Karpinsky Russian Geological Research Institute, St. Petersburg.

The morphometric characteristics of Late Pleistocene Caspian basins were calculated with the use of GIS technologies [21]. GTOPO30 global digital elevation model (DEM) has been applied, using the Caspian Sea navigation map (http://www.caspianenvironment.org/dim/gis/isobat_as cii.zip), digitized by Z. Kerimov.

\section{RESULTS}

\section{The Lower Volga}

The studied sections along the Lower Volga (Fig. 3) included both Khazarian and Khvalynian marine and alluvialmarine sediments. The Khazarian marine deposits usually had the basal layer consisting of clay and quartz pebbles, ferruginous-manganese crusts, carbonaceous concretions, and with large concentrations of rolled brackish and freshwater mollusk shells. The typical Upper Khazarian sediments include brownish-brown clays, coarse-grained, crossand horizontally laminated sands, 4-12 m thick. Prevailing sediments are the sand and silt. Frequent litho-facial variability observed in the Upper Khazarian sediments is apparently due to the proximity of the Volga Delta (Fig. 4). Upstream marine and alluvial-marine sediments are gradually replaced by the continental alluvial facies.

The Khazarian sediments include a rich mollusk assemblage with Didacna surachanica and other brackish-water species. The abundance of the latter species rises upstream, indicating the reduced salinity in this direction. Thick-wall shells D. surachanica (recorded at Seroglazka) become smaller (at Vladimirovo), being substituted by D. ex.gr. trigonoides group (at Yenotaevka). The same pattern is observed in the vertical section, the reduced salinity is evidenced in the upper section at Kopanovka by the occurrence of D. eulachia in an assemblage that includes fresh-water molluscan fauna. The Ostracoda show the similar pattern.

Paleomagnetic measurements of the marine and deltaic Upper Khazarian sediments confirmed the occurrence of reverse geomagnetic polarity in five sections (excepting the Tsagan-Aman section), which we referred to as the Seroglazka excursion. Its age, based on Th-U, TL and ESR measurements, is estimated in the range from $117 \pm 7.5$ to $89 \pm 11$ ka BP (Table 1).

We obtained palaeoenvironmental summer and spring characteristics for Late Khazarian Sea using Didacna surachanica and Didacna crassa nalivkini shells (Table 2). Summer and spring characteristics of the Khvalynian Sea were obtained using Didacna protracta protracta shells.

In all studied sections, the Upper Khazarian sediments were overlain by the marine Lower Khvalynian sands and 'chocolate' clays. We were able to obtain environmental characteristics for the principle phases in the existence of 


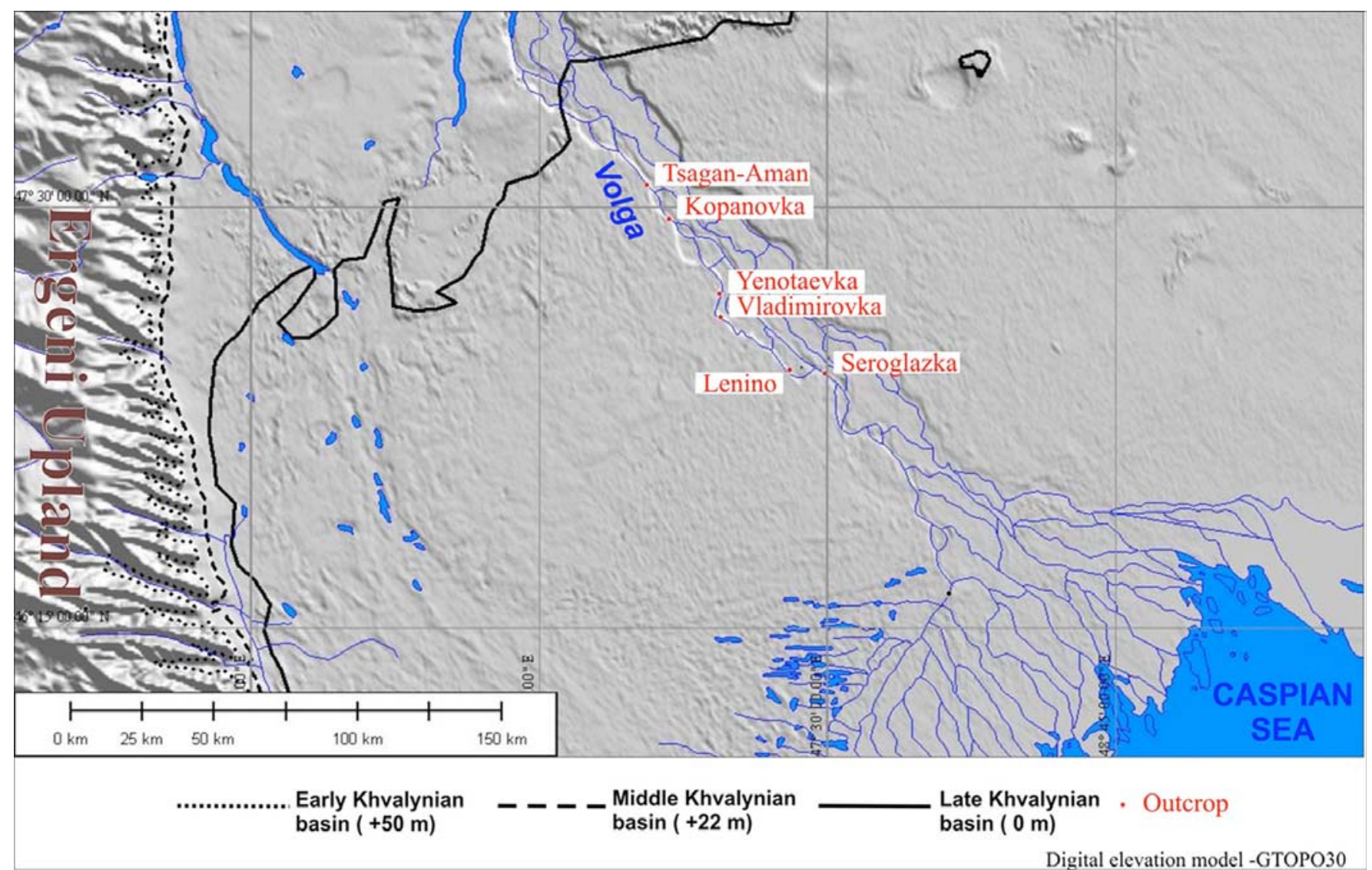

Fig. (3). Studied sites in the Lower Volga area.

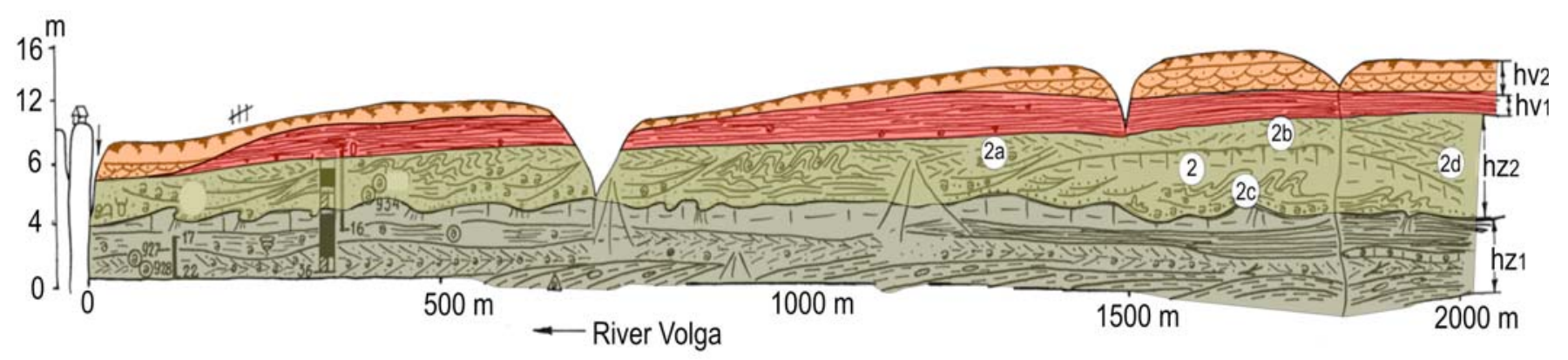

Fig. (4). Upper Khvalynian sediments at Kopanovka sequence. Key. 1 - cross-laminated sand (coastal sand barrier lithofacies); 2 - crosslaminated sand (central part barrier lithofacies); 2a - riverward slope 2c - sand barrier, central part; 2c seaward slope; circles: sampling; black bars: reverse geomagnetic polarity.

Table 1. Radiometric Age of Khvalynian and Khazarian Deposits in the Lower Volga Area

\begin{tabular}{|c|c|c|c|c|c|c|c|}
\hline \multirow{2}{*}{\multicolumn{2}{|c|}{ Events }} & \multicolumn{5}{|c|}{ Age in ka BP. } & \multirow[b]{2}{*}{ MIS } \\
\hline & & $\begin{array}{c}(1) \\
\text { Th/U }\end{array}$ & $\begin{array}{c}(2) \\
\text { ESR }\end{array}$ & $\begin{array}{l}(3) \\
\text { TL }\end{array}$ & $(\mathbf{1 - 3})$ & ${ }^{14} \mathrm{C}$ & \\
\hline \multicolumn{2}{|c|}{ Upper Khvalynian } & & & & & $16-9$ & 2 \\
\hline Lower Khvalynian & & & & & & $30-17$ and $<30$ & $\begin{array}{c}2-3 \\
3\end{array}$ \\
\hline Upper Khazarian & Regression & $1,22-87$ & $105-85$ & $127(130)-89$ & $\begin{array}{c}117(114)-89(85) \\
127(130)-122\end{array}$ & & $\begin{array}{l}5 \mathrm{~d}-\mathrm{a} \\
5 \\
5 \mathrm{e}\end{array}$ \\
\hline
\end{tabular}


this marine basin: the initial transgression (shelly sands at Lenino), the transgression maximum (the coquina at the bottom of the 'chocolate' clays at Nikolskoye and the coquina, on top of the 'chocolate' clays at Tsagan-Aman) and the regression (the shells in sandy loam overlaying the chocolate clays, at Nikolskoye). The coastal microfacies at Kopanovka included the mammal fauna: a skull of a small cave bear (Ursus rossicus Boris) identified by G.F. Baryshnikov (Institute of Zoology, St. Petersburg) as well as bones of small mammals: water vole (Arvicola terrestris L) and shrew (Sorex sp.).

Table 2. Environmental Characteristics of Caspian Basins

\begin{tabular}{|c|c|c|c|c|}
\hline \multicolumn{2}{|c|}{ Basins } & $\begin{array}{c}\text { Temperature } \\
{ }^{\circ} \mathrm{C}\end{array}$ & $\begin{array}{l}\text { Salinity } \\
(\% \circ)\end{array}$ & $\begin{array}{c}\delta^{18} \mathrm{O} \\
(\% o)\end{array}$ \\
\hline \multirow{2}{*}{\multicolumn{2}{|c|}{ Upper Khvalynian }} & +16.5 & 1.5 & -9.0 \\
\hline & & +13.5 & 1.3 & -9.1 \\
\hline \multirow{4}{*}{$\begin{array}{c}\text { Lower } \\
\text { Khvalynian }\end{array}$} & \multirow{2}{*}{ Regression } & +14.0 & 3.5 & -7.7 \\
\hline & & +10.0 & 0.0 & -10.3 \\
\hline & \multirow{2}{*}{ Transgression } & +19.0 & 5.4 & -6.4 \\
\hline & & +15.0 & 1.2 & -9.2 \\
\hline \multirow{4}{*}{$\begin{array}{c}\text { Upper } \\
\text { Khazarian }\end{array}$} & \multirow{2}{*}{ Regression } & $+14.5 \div+17.5$ & $2.5 \div 6.5$ & $-5.5 \div 8.0$ \\
\hline & & $+6.0 \div+7.5$ & 0.0 & -10 \\
\hline & \multirow{2}{*}{ Transgression } & $+21.0 \div+13.5$ & 8 & -4.5 \\
\hline & & $+16.5 \div+13.5$ & 10 & -3.5 \\
\hline
\end{tabular}

\subsection{Sukhaya Mechetka (Volgograd) Palaeolithic Site}

The Palaeolithic site in the city of Volgograd, has been discovered in 1951 and excavated in 1952 by S.N. Zamyatin. The site was located in a deep ravine of Sukhaya Mechetka stream. Two terraces of Khvalynian age are distinguishable at the absolute altitude of 50-45 and 25-34 $\mathrm{m} \mathrm{[22].} \mathrm{The} \mathrm{both}$ terraces are formed by the marine sediments consisting of sand and clay, gradually transforming from one to another. The both facies contain the mollusc fauna which include Didacna ex gr. ebersini Fed., D. parallela Bog., Adacna plicata Eichenw., and Dreissenia polymorpha Pall.

The Palaeolithic deposits were found at the depth ranging from $20-25$ to $38 \mathrm{~m}$, on the surface and partly inside a palaeosoil, beneath c. $4 \mathrm{~m}$ thick Khvalynian sand and c. $1.5 \mathrm{~m}$ thick 'Atelian loam' (Fig. 5). The pollen analysis of the palaeosoil has shown the prevalence of herbs with Artemisia and Chenopodiaceae and limited amount of spruce, denoting the cold-resistant vegetation of steppe and semi-desert type. Similar pollen spectra were discovered in the overlaying 'Atelian loam'.

Archaeological inventory is dominated by side-scrapers, and includes bifacial foliate points, knives, with a specific Volgograd-type knife, and a variety of bifacial tools [23, 24] (Fig. 6). This industry is viewed as belonging to the 'Eastern Micoque': a late Mousterian facies, stemming from Central Europe [25]. Animal bones recovered from the archaeological layer include the mammoth, red deer, wolf, antelope saiga and aurochs. The Atelian loam contained the bones of wild horse and reindeer.

\section{The Kuma-Manuch Spillway}

The Kuma-Manych valley is located along a tectonic depression of NW-SE direction in an area of Karpinsky Swell, on the southern margin of the Scythian platform. Its highest point, forming the Caspian-Black Sea watershed at $25 \mathrm{~m}$ a.s.1. lies in the mouths of Kalaus and Western Manych rivers, their merged fans forming a sediment plug. The widest section, $50-55 \mathrm{~km}$ wide and $180 \mathrm{~km}$ long, is presently taken up by Manych Gudilo Lake (Fig. 7).

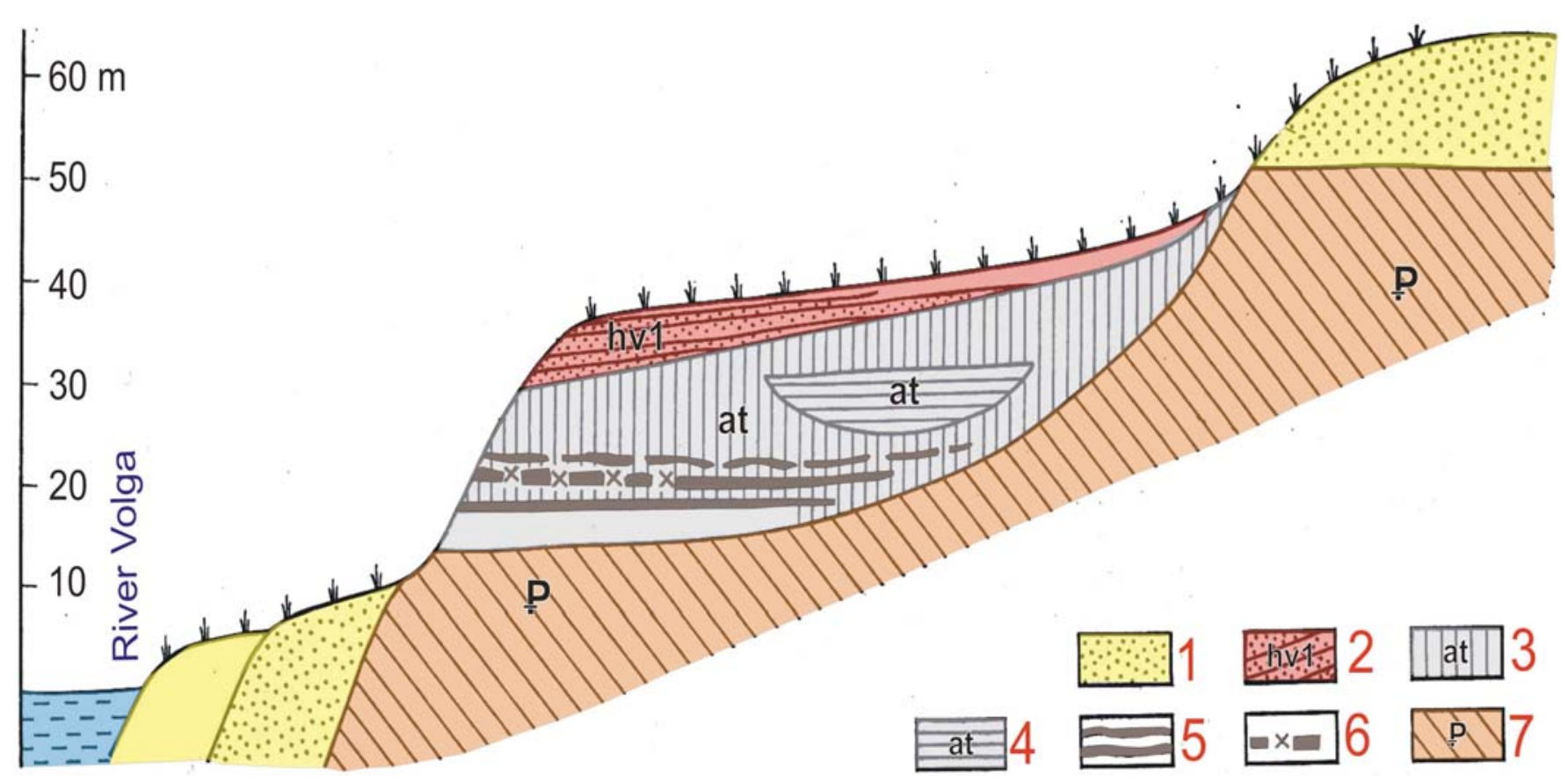

Fig. (5). Volgograd site cross-section [23]. Key: 1 - sand; 2 - stratified Khvalynian silt; 3 - Atelian loam; 4 - Atelian lake sediments; 5 - palaeosoil; 6 - archaeological layers. 


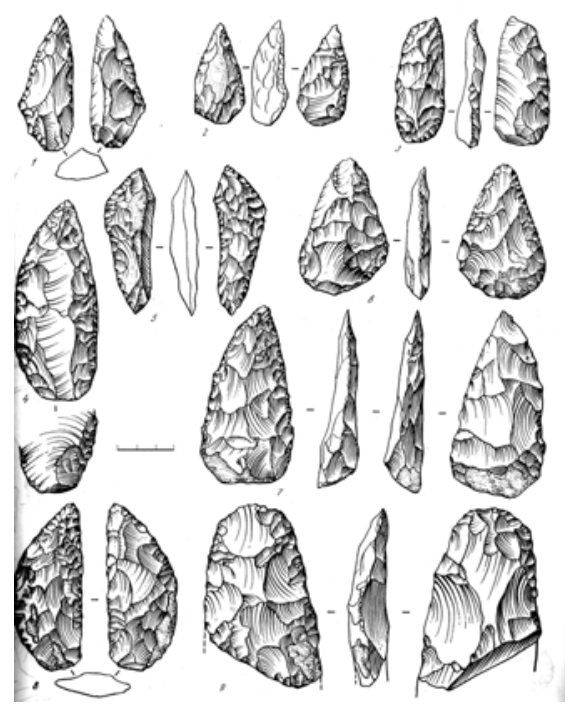

The Khvalynian sediments with the typical Khvalynian mollusk fauna are recognizable all along the valley, they consist of clays and silts and, less frequently, sands. By both their texture and composition these sediments are similar to the 'chocolate' clay of the Lower Volga. They consist of poorly rolled quartz grains, with less common occurrence of mica, carbonate nodules, glauconite, feldspars, and rarely, epidote, hornblende, zoisite, tourmaline, and zircon. Authigenic minerals, predominantly iron hydroxide, gypsum (single crystals and aggregates) and glauconitic, are less common. Clay minerals are represented by smectite, kaolinite, montmorillonite, chlorite, and hydromica. Their reddishbrown color is supposedly due to iron-rich clay minerals. Locally the clays are interbedded with thinly laminated (1-2 $\mathrm{cm})$ greenish-gray and dark gray clays. Khvalynian sediments form a row of parallel ridges on the bottom of Manych Gudilo Lake, 10 to $25 \mathrm{~km}$ long, 20-30 m high; their width ranging from a few hundred meters to $1-2 \mathrm{~km}$ (Fig. 8).

Fig. (6). Volgograd site. Stone tools [24].

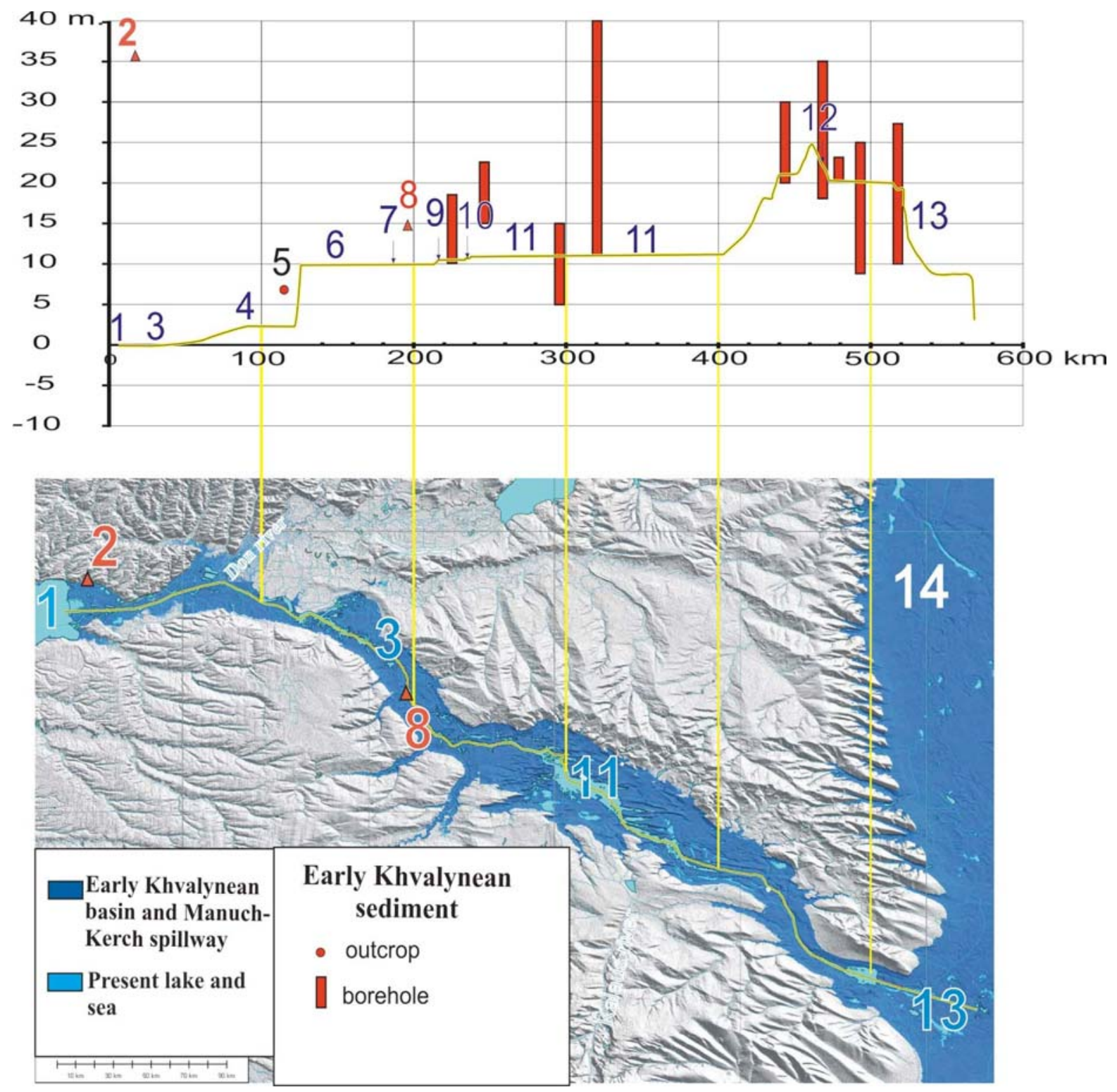

Fig. (7). Kumo-Manych Spillway (GIS reconstruction). 


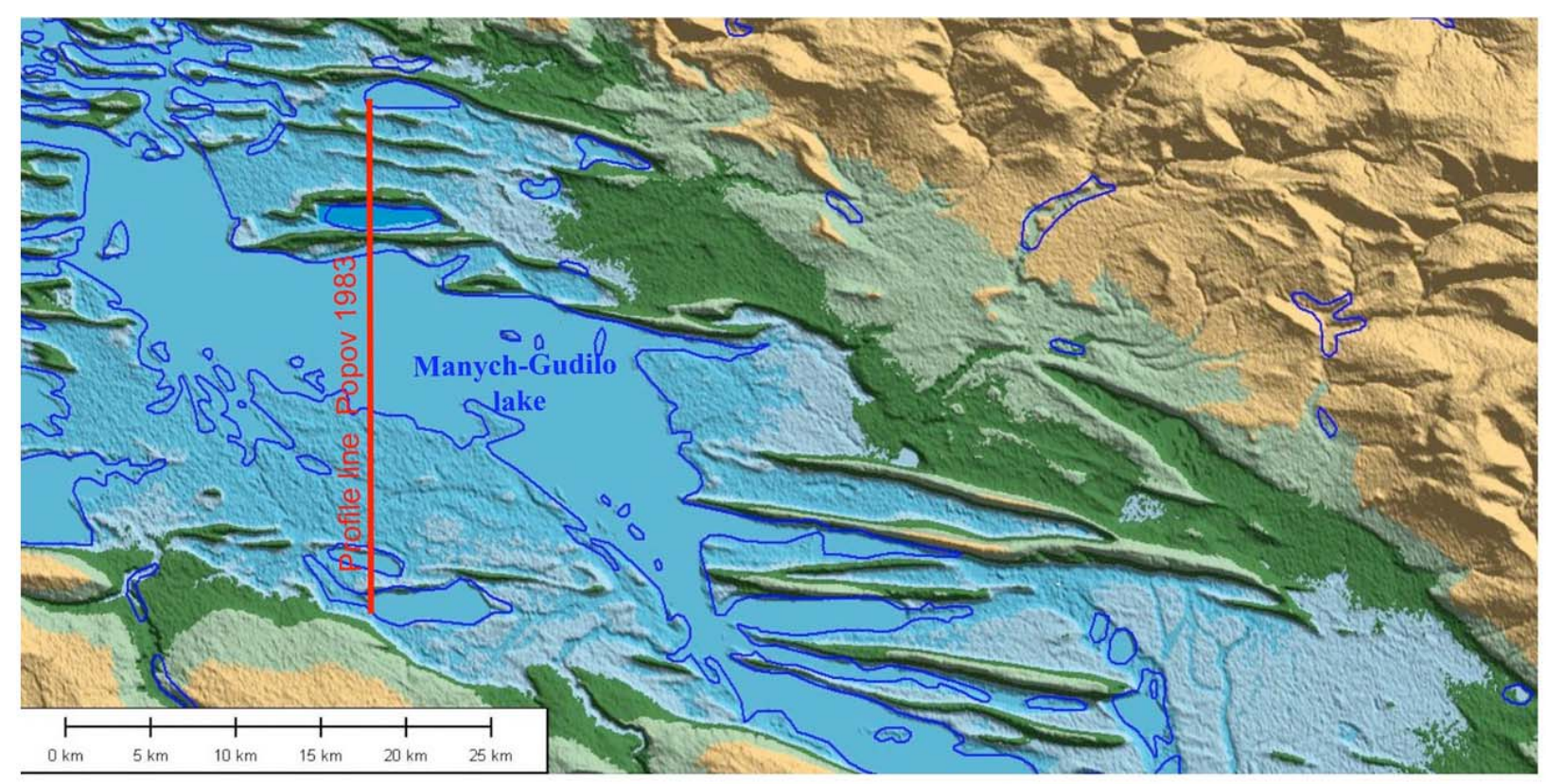

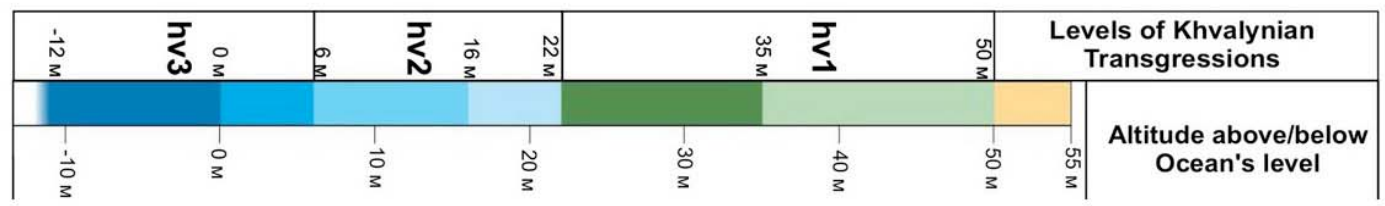

Fig. (8). Manych Gudilo Lake section (GIS reconstruction).

\section{The Dagestan Coast}

The Dagestan's coastal area which forms the southern extension of the Caspian Lowland facing the anticline heights of the Greater Caucasus' outer ridges. Its mantle is formed by marine Quaternary deposits which thickness along the axis of the Terek-Sulad Delta attains 1,000 m. Among the staircase of the marine terraces of Pleistocene age in the coastal area, nine Khvalynian levels are distinguishable at the absolute altitudes of $48,+35,+22,+16,+6,-$ $5, \div 0,-6$, and $-12 \mathrm{~m}$.

H.A. Amirkhanov [26] discovered and studied seven Mousterian sites in the lower stretches of Manas-Ozen' River, three of which are located below the maximum level of the Khvalynian transgression. The Manas-Ozen' I site was found on the relic of the first terrace on the right bank of the river south-east of Manaskent village. The lithic inventory includes five objects, a side-scraper on a small flake, a biface reduction flake, and two flakes, all of them with a strong patina. The Manas-Ozen' 2 site has been found on the terrace of the river right bank, east of the railway line. The $26 \mathrm{ob}-$ jects include four Levallois-type flakes, one a fragment of a massive polyhedral core, and numerous flakes. The ManasOzen' 3 site lays on a promontory of the upper terrace extending on the flood-plain on the outskirts of Manaskent village. The inventory includes three thick flakes of subrectangular shape with broad butts and large percussion bulbs. All three sites include the identical raw material and are stylistically similar. Hence they all may be considered as belonging to the Mousterian. The scarcity of the finds and the apparent lack of archaeological layers suggest that these were temporal short-lived sites. As on-the-spot inspection of these sites has shown, these sites lay on the surface of the Khvalynian terraces at an absolute height of 35-45 m (Fig. 9).

\section{Manyshlak Peninsula}

The Mangyshlak is an oil and gas rich peninsula in the north-eastern part of the Caspian basin. The limestone of Sarmatian age forms a huge tableland lying between 70 and $132 \mathrm{~m}$ absolute height. This plateau with desert-like vegetation is separated by steep escarpments ('chinks') from the coastal plain, where a system of aggradational and wave-cut terraces is acknowledgeable. Several allegedly Early Palaeolithic sites were reported by A.G. Medoev [27] from the area of Saratysh Bay on the Mangyshlak Peninsula. They included different types of hand-axes and the cores of pseudoLevallois type. The comparison of the geomorphic map published by Medoev (compiled by Potapova) with Google Earth satellite imagery shows that the sites on the Saratysh Bay are situated on the terrace with an absolute altitude of 45-50 m, which corresponds to the level of Early Khvalynian transgression (Fig. 10).

\section{Krasnovodsk Peninsula}

The low-laying area between the Krasnovodsk plateau and the Greater Balkhan ridge, the westernmost extension of the Kopet-Dag Mountains, formed a terraced plain consisting of rows of sand barriers. During Late Pleistocene there lay a bay of the Caspian Sea, into which emptied the Uzboy River (Fig. 11).

Several open-air sites containing Mousterian-type bifacial tools were discovered in 1976 during archaeological surveys near Belek Station, west of the town of Djebel in 


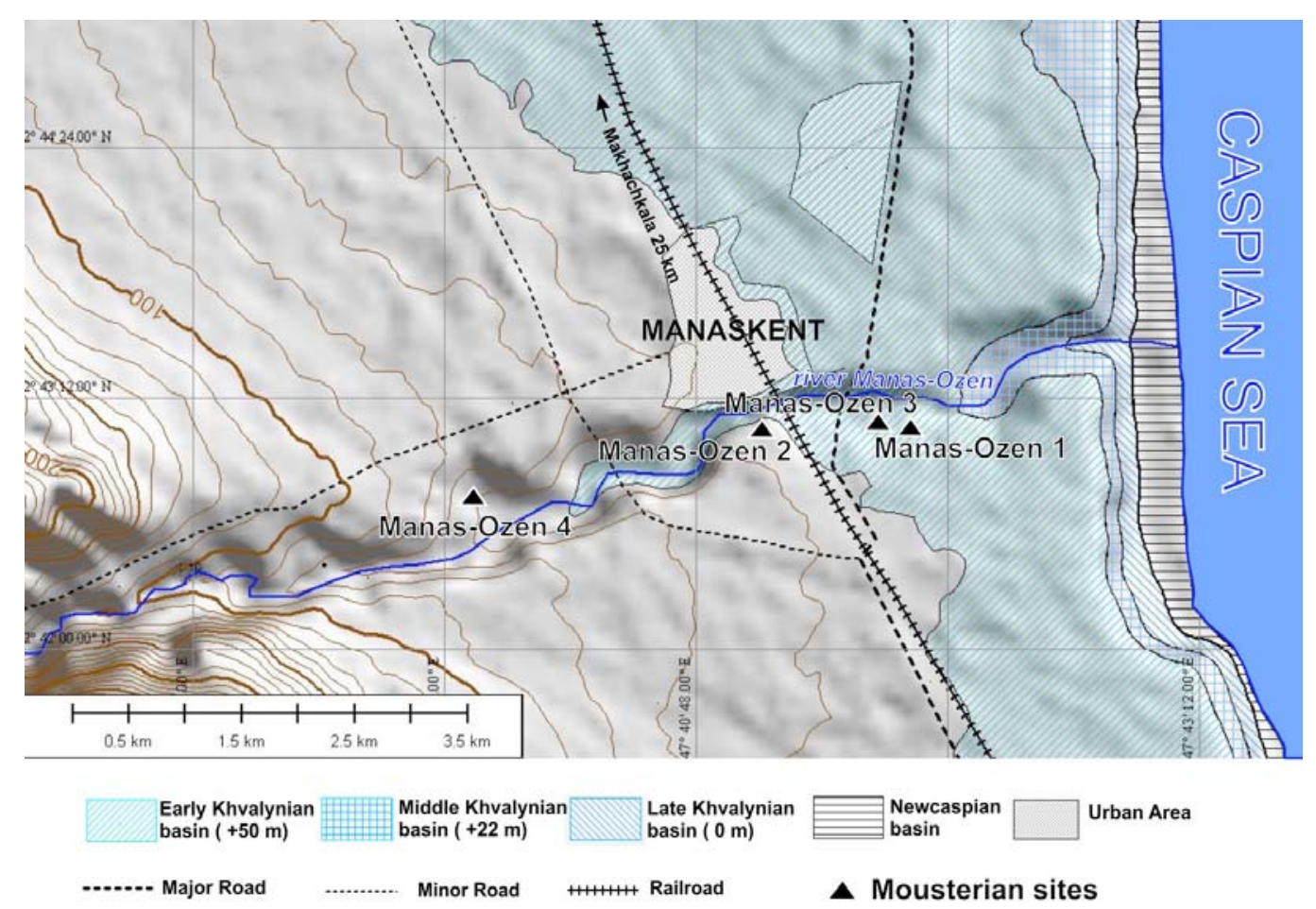

Fig. (9). Manas-Ozen' sites, Dagestan (GIS reconstruction).

western Turkmenistan [28]. The archaeological collection includes several bifacial tools of apparently Mousterian age, similar to these which had been found further west on the Krasnovodsk Peninsula. These tools were found on the surface of a barrier beach at an absolute height of $5 \mathrm{~m}$ below the ocean level (Fig. 12). This altitudinal position enables one to deem it as corresponding to the Late Khavalynian transgression This age was further substantiated by a lens of marine shells below the sand barriers with typical Upper Khavalynian molluscs: Didacna trigonoides praetrigoboides; $D$. baeri; D. pyramidata; D. parallela.

\section{DISCUSSION}

As show quantitative simulations [29], the Caspian Sea oscillations were largely controlled by the Volga River discharge. According to Kislov and Toporov [30, 31], the relative Volga's contribution to the total water influx into the Caspian Sea remained basically unchanged throughout the Pleistocene and Holocene ( $88 \%$ at the LGM versus $84 \%$ presently). Yet according to the same writers the total river runoff during the Glacial maximum diminished by $40-45 \%$, due to a substantial decrease of precipitation (by c. $34 \%$ compared to the presentday conditions). From this perspective, the Atelian regression may be viewed as corresponding to the LGM.

The reported above the isotopic evidence (Table 2) strongly suggests that both the Khazarian and Khvalynian transgressions occurred in an environment of mild climatic conditions. The dates obtained by various radiometric techniques (Table 1) suggest the time limits of the Late Khazarian transgression as 122-87 ka BP (Th-U), 105- $85 \mathrm{ka} \mathrm{BP}$ (ESR), and 127(130)-89 ka BP (TL). These dates are largely consistent with the age estimates of the Eemian (the last in-

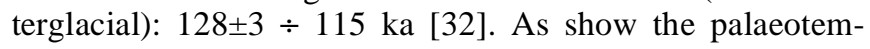

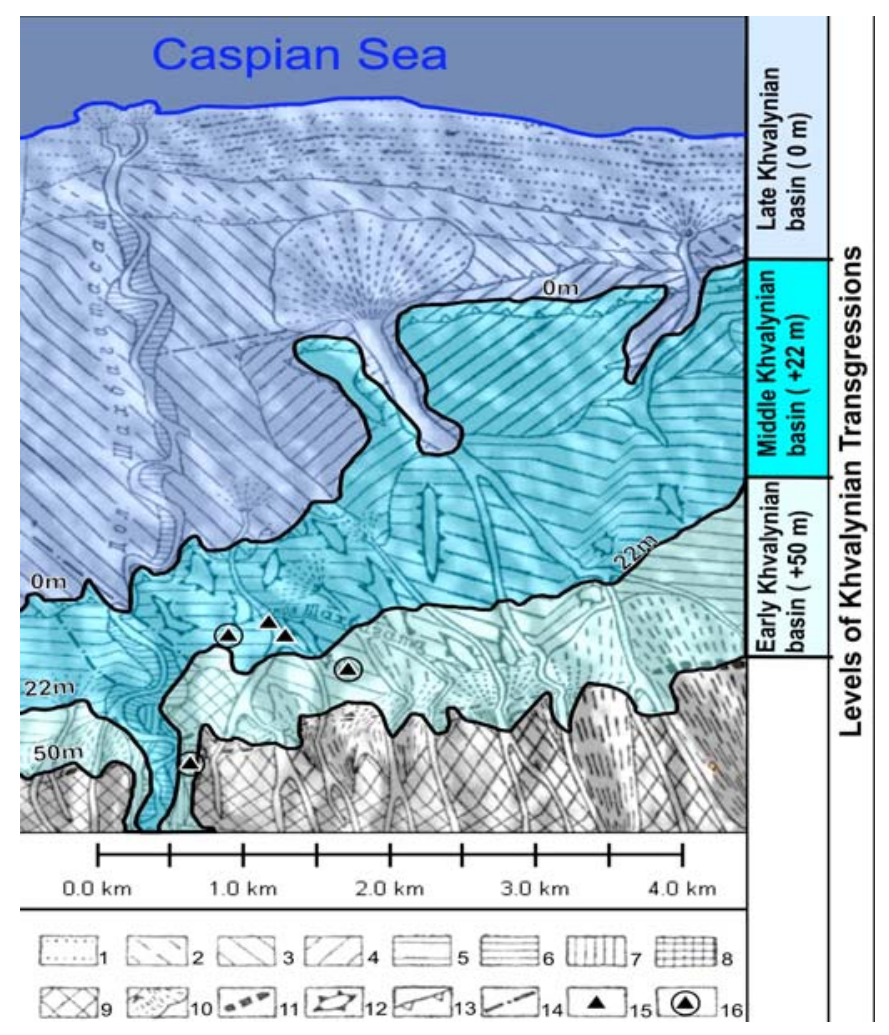

Fig. (10). Saratysh Bay sites, Mangyshlak Peninsula [27]. Key: Marine terraces: 1 - Neocaspian; 2 - Late Khvalynian; 3 - Early Khvalynian; 4 - Bakunian abrasion terrace; 5 -Neogenic (?) aggradation terrace. River terraces: 6 - flood-plain; $7-1^{\text {st }}$ terrace; $8-2^{\text {nd }}-$ $4^{\text {th }}$ terraces; 9 - Tyubkaragan plateau; 10 - alluvial fans and rock trains; 11 - Early Khvalynian sand barrier; 12 - residual islands; 13 - wave-cut cliff; 14 - fault-line; 15 - surface Palaeolithic sites; 16 excavated Palaeolithic sites. 


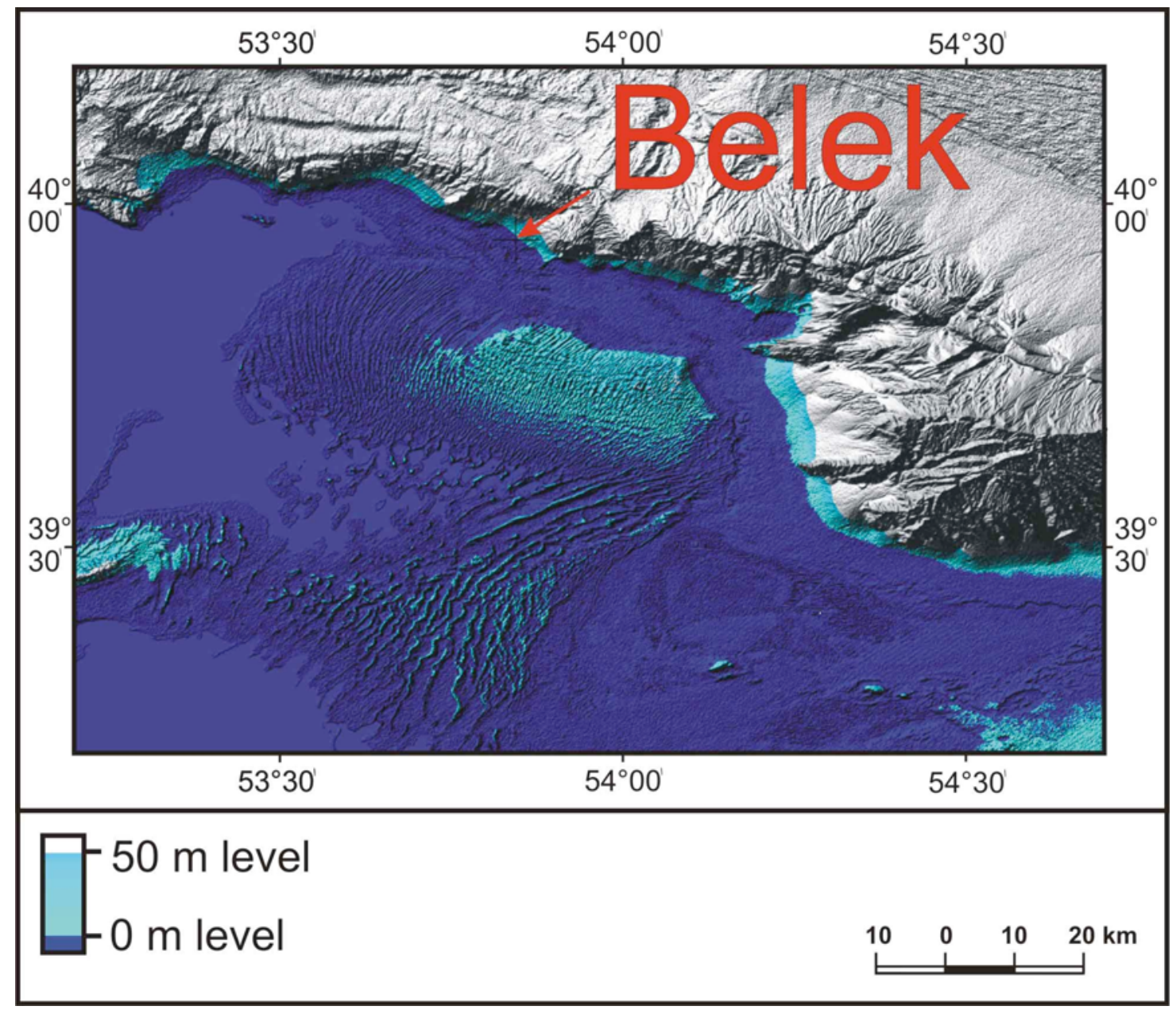

Fig. (11). Krasnovodsk Peninsula (GIS reconstruction).

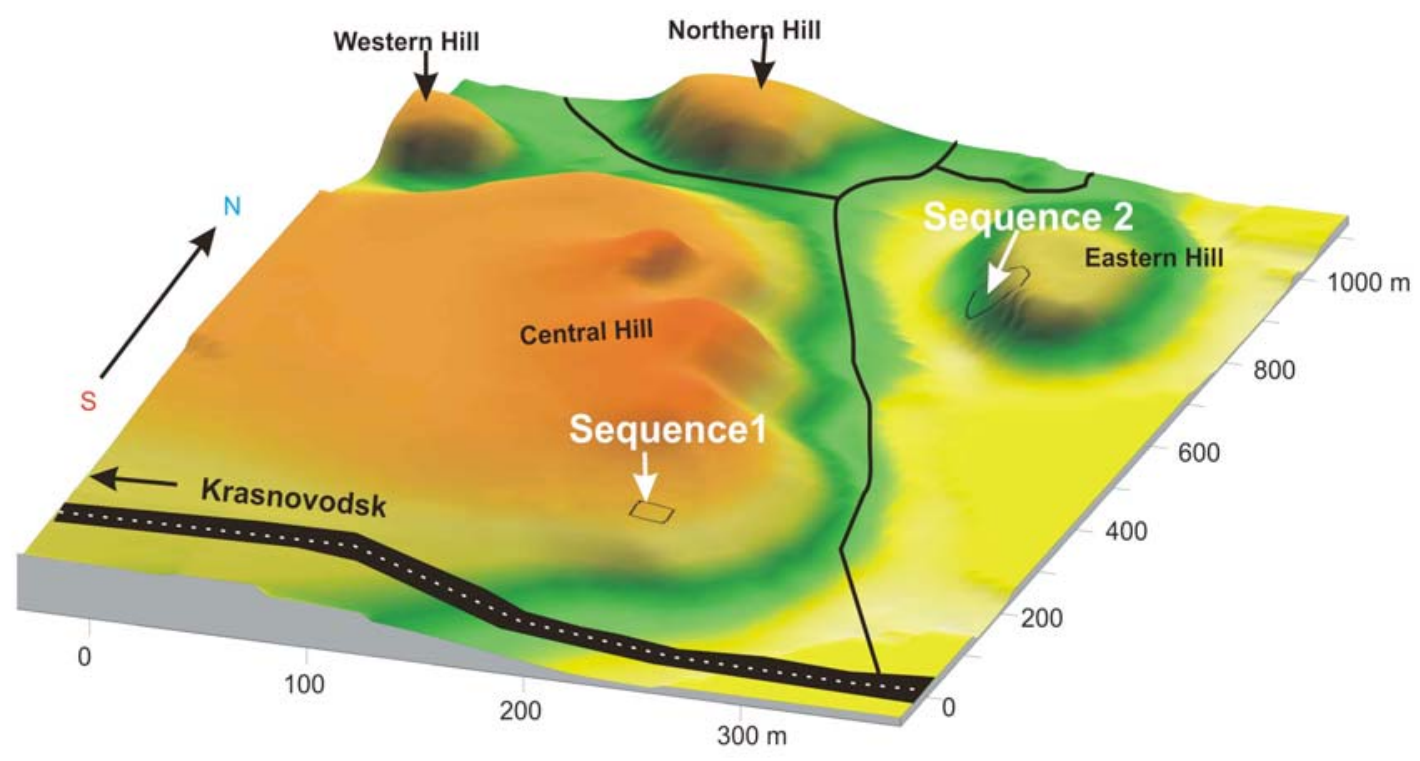


perature estimates of Khazarian sea water based on the combined use of oxygen isotope ${ }^{18} \mathrm{O} /{ }^{16} \mathrm{O}$ ) analyses, and the measurement of $\mathrm{Ca} / \mathrm{Mg}$ ratio in the aragonite extracted from Didacna surachanica and Didacna crassa nalivkini shells, both the spring and summer seawater temperatures were by $2-3^{\circ} \mathrm{C}$ higher than presently. Salinity with seasonal variations of 2-3\%o was basically similar to that of today in the Caspian high seas. The oxygen isotopic composition of mollusks suggests it being in spring and summer isotopically lighter by $2-3 \%$ as compared to the present-day Northern Caspian sub-basin. It further suggests an increased influx of fresh melt water and the abundant precipitation during the warm seasons. The climate in Lower Volga area was allegedly very warm and humid in summer and, cold and dry in winter. The regression of Late Khazarian basin (117- 87(89) ka BP, coincided with the inverse geomagnetic polarity, the Seroglazka-Blake excursion. At the initial regression stage (117-114 ka BP) both the summer and spring seawater temperatures decreased by $5^{\circ} \mathrm{C}$. During the subsequent period (114-106 ka BP) the temperature further decreased by $1^{\circ} \mathrm{C}$ in summer and by $3^{\circ} \mathrm{C}$ in spring. The range of seasonal salinity variations at the beginning of regression reached 5-6 $\%$; supposedly due to the seasonal shift of atmospheric precipitation, increasing in winter and decreasing in summer. During the regression, the ratio of isotopically lighter water increased almost three-fold apparently due to the onset of a colder climate.

This temperature trend is quite similar to that recognizable for the Eemian interglacial. The existing simulations of Eemian January temperature anomalies, which are generally consistent with pollen-based reconstructions, show the positive deviations over the Eastern Europe in the order of $2-5^{\circ} \mathrm{C}$ [33]. Reconstructions based on deep pollen sequences in Germany and France demonstrate a rapid decline of temperature (in the order of $8^{\circ} \mathrm{C}$ ) by the end of the interglacial period.

The most reliable ${ }^{14} \mathrm{C}$ dates obtained for the samples of both Lower and Upper Khvalynian deposits [12, 19, 34] (Table 3) show a unimodal distribution (Fig. 13). Most of the dates are in the time-span between 10 and $17 \mathrm{ka}$ (uncalibrated), whereas the remaining dates (both the younger and the older ones) appear to be outliers which can be reasonably ignored. The radiocarbon dates most often belong to a much narrower range of 13.6-11.8 ka (uncalibrated), which can be accepted as the most probable age of the peak of the Khvalynian transgression.

During the Early Khvalynian transgression maximum the summer temperatures were close to the present-day values; both the temperature and salinity reaching their all-time maximums. High spring temperatures contributed to an intense snow melting, and reduced salinity thus making the water 'lighter' by 3-4\%o as compared to its summer values while the total oxygen isotopic composition was by $1-2 \%$ o 'heavier' than at the initial transgression phase. During the Late Khvalynian regression both the spring and summer seawater temperatures were by $+5^{\circ} \mathrm{C}$ lower than at its transgression phase. The isotopic composition of water oxygen was the most 'lightened' for the entire period of Khvalynian Sea.
Table 3. Radiocarbon Dates of Khvalynian Deposits on the Daghestani Coast and the Lower Volga Area (After Rychagov 1997; Svitoch1991; and Leonov et al., 2002)

\begin{tabular}{|c|c|c|}
\hline Basin & $\begin{array}{c}\text { Lab } \\
\text { Index }\end{array}$ & $\begin{array}{c}\text { C-14 Dates BP } \\
\text { Uncalibrated }\end{array}$ \\
\hline \multirow{34}{*}{$\begin{array}{c}\text { Upper } \\
\text { Khvalynian }\end{array}$} & МГУ-796 & $07330+-500$ \\
\hline & MGU-794 & $07700+-250$ \\
\hline & LU-842 & $08850+-700$ \\
\hline & MGU-95 & $09700+-190$ \\
\hline & LU-479A & $11210+-850$ \\
\hline & LU-479B & $11340+-160$ \\
\hline & MGU-130 & $11300+-400$ \\
\hline & LU-193A & $11750+-120$ \\
\hline & LU-193B & $12480+-150$ \\
\hline & MGU-IOAN-34(A+B) & $12200+-240$ \\
\hline & MGU-IOAN-39 & $12800+-200$ \\
\hline & LU-423B & $12330+-140$ \\
\hline & MO-460 & $12350+-150$ \\
\hline & LU-424A & $13110+-490$ \\
\hline & LU-424B & $12720+-400$ \\
\hline & LU-192A & $13140+-150$ \\
\hline & LU-192B & $13200+-250$ \\
\hline & LU-1409 & $13540+-130$ \\
\hline & LU-1361 & $13920+-740$ \\
\hline & IOAN-129 & $14430+-230$ \\
\hline & IOAN-130 & $14240+-640$ \\
\hline & GIN-187 & $14030+-250$ \\
\hline & MO-457 & $14400+-230$ \\
\hline & LU-460A & $14600+-210$ \\
\hline & LU-179 & $14700+-130$ \\
\hline & LU-73 & $15020+-500$ \\
\hline & LG-118 & $15020+-140$ \\
\hline & MGU-97 & $15500+-350$ \\
\hline & MGU-IOAN-33 & $15100+-300$ \\
\hline & IVP-226 & $5130+-400$ \\
\hline & IVP-211 & $20500+-1200$ \\
\hline & IVP-229 & $20000+-1500$ \\
\hline & IVP-213 & $21590+-1200$ \\
\hline & IVP-222 & $22400+-900$ \\
\hline \multirow{7}{*}{$\begin{array}{c}\text { Lower } \\
\text { Khvalynian }\end{array}$} & LG-147 & $08680+-170$ \\
\hline & MGU-1042 & $09500+-700$ \\
\hline & MGU-1044 & $09700+-330$ \\
\hline & MGU-1039 & $10770+-330$ \\
\hline & MGU-1037 & $11280+-700$ \\
\hline & LU-425B & $11740+-180$ \\
\hline & MGU-98 & $11600+-140$ \\
\hline
\end{tabular}




\begin{tabular}{|c|c|c|}
\hline Basin & $\begin{array}{c}\text { Lab } \\
\text { Index }\end{array}$ & $\begin{array}{c}\text { C-14 Dates BP } \\
\text { Uncalibrated }\end{array}$ \\
\hline & MGU1034 & $11290+-380$ \\
\hline & LU-1358 & $11390+-200$ \\
\hline & LU-841 & $11490+-380$ \\
\hline & LU-426B & $11600+-1000$ \\
\hline & MGU-792 & $11760+-200$ \\
\hline & LU-864A & $11830+-200$ \\
\hline & MGU-793 & $11820+-250$ \\
\hline & MGU-IOAN-38 & $12150+-200$ \\
\hline & GIN-66 & $12500+-140$ \\
\hline & LU-1359 & $12010+-340$ \\
\hline & LU-1357 & $12210+-150$ \\
\hline & MGU-99 & $12050+-090$ \\
\hline & AA37204 & $12060+-130$ \\
\hline & AA37366 & $12120+-180$ \\
\hline & AA37203 & $12445+-075$ \\
\hline & AA 37365 & $12470+-080$ \\
\hline & LU-490A & $12520+-140$ \\
\hline & AA37363 & $12580+-070$ \\
\hline & MGU-19 & $12600+-240$ \\
\hline & LU-1353 & $12690+-100$ \\
\hline & AA37201 & $13070+-100$ \\
\hline & MGU-25 & $13100+-300$ \\
\hline & AA 37202 & $13170+-085$ \\
\hline & AA37368 & $13240+-045$ \\
\hline & MGU-1491 & $14300+-680$ \\
\hline & LG-93 & $14080+-100$ \\
\hline & MGU-18 & $15500+-300$ \\
\hline & MGU-18 & $15600+-350$ \\
\hline & MGU-97 & $16000+-330$ \\
\hline & LU-828 & $16700+-550$ \\
\hline & IOAN-90 & $17000+-350$ \\
\hline & MGU-22 & $18460+-220$ \\
\hline & IOAN-91 & $21500+-300$ \\
\hline & IOAN-93 & $22100+-730$ \\
\hline & IOAN-94 & 23450 \\
\hline & IOAN-92 & $23400+-500$ \\
\hline & IOAN-132 & $24000+-1300$ \\
\hline & LU-826 & $24200+-700$ \\
\hline & LG-149 & $24830+-170$ \\
\hline & MGU-23 & $30700+-1500$ \\
\hline
\end{tabular}

The spring and summer seawater temperatures further increased in the Late Khvalynian basin, by $2-3^{\circ}$ as compared to the Early Khvalynian regression phase; the spring and summer salinity in the western part of the Northern Caspian becoming almost identical to the recent values. The overall seawater oxygen isotopic composition became 'heavier' by $1 \%$ without notable seasonal changes (Table $\mathbf{1}$ ).

Based on the available radiometric evidence, one may ascertain that the early Khvalynian transgression was basically coeval with the mild Late Glacial intervals in the higher latitudes. The suggested age of the Khvalynian transgression is close to the age of the widespread warming recognisable in the European Late Glacial records [32]. Recently available data for the long sequence at Dziguta on the Black Sea coast [35] indicate two warm phases at 12-11.7 and 11.5 - $11 \mathrm{ka}$ (uncalibrated), separated by a short-lived cooling. Palaeotemperature reconstructions for Western Europe based on the fossil Coleoptera suggest a rapid temperature rise at the rate of $7^{\circ} \mathrm{C}$ per century, reaching the values above the presentday level [36]. The pollen-based reconstructions for the Allerød oscillation (11.8 - $11.0 \mathrm{ka}$ uncalibrated) in Eastern Europe [37] show the July temperature being only slightly cooler than now (by $2^{\circ} \mathrm{C}$ ) over the greater part of the East European Plain.

During the course of this transgression the volume of the Caspian basin increasing 6.5 fold, as compared to that of the preceding Atelian one. The transgression supposedly proceeded in a quick alteration of successive sea-level fluctuations and in some cases had a catastrophic character.

Using the GIS methodology we obtained the following morphometric characteristics for main Pale Pleistocene Caspian basins (Table 4). The Atelian basins which mean level stood at $-140-120 \mathrm{~m}$ absolute height had an area of about $131.5 \mathrm{~km}^{2}$, which is about one third of that of the present-day Caspian Sea. The small value of coast irregularity (1.06) suggests that the coastline being located on the bottom of Khazarian Sea.

The Early Khazarian basin reached the absolute altitude of $+50 \mathrm{~m}$ and occupied an area of $952.000131 .5 \mathrm{~km}^{2}$ (or $978.600 \mathrm{~km}^{2}$ with the Volga estuary). The area of the adjoining Aral-Sarylamysh basin was $222,000 \mathrm{~km}^{2 .}$ This basin exceeded 2.5 times the area of present-day Caspian Sea and 6.5 times, that of the preceding Atelian basin. The high value of coast irregularity (2.20) due tom the location of its coastline at the foothills of Yergeny, General Syrt Uplands and along the escarpments ('chinks') of Ust-Urt Plateau. The lower stretches of the Volga and Ural rivers formed impressive estuaries. The sea submerged the greater part of the Kura valley in the Caucasus, western part of the Mangyshlak Peninsula and the entire Western Turkmenian Lowland. The Late Khvalynian basin stood at the mean ocean level. Its area is estimated as $699.700 \mathrm{~km}^{2}$ with the length of the coastline of $6,844 \mathrm{~km}$. The coast irregularity is 1.43 .

If one accepts this scenario, the age of the 'ManychKerch-Spillway' via which the Khvalynian water was discharged into the Black Sea reached its highest activity during the peak of the Khvalynian transgression at $13.6-11.8 \mathrm{ka}$ (uncalibrated) when the level reached the absolute altitude of $50 \mathrm{~m}$. The total length of the spillway was 950-1000 km (depending on the sea levels), its width varying between 50-55 and $10 \mathrm{~km}$, and the depth of about $30-50 \mathrm{~m}$. Taking into account the differences in the levels of the Caspian $(+50 \mathrm{~m})$ the Black Sea $(-80$ to $-100 \mathrm{~m})$, the spillway bottom gradient should be in the order of 0.0001 . The stream velocity is es- 


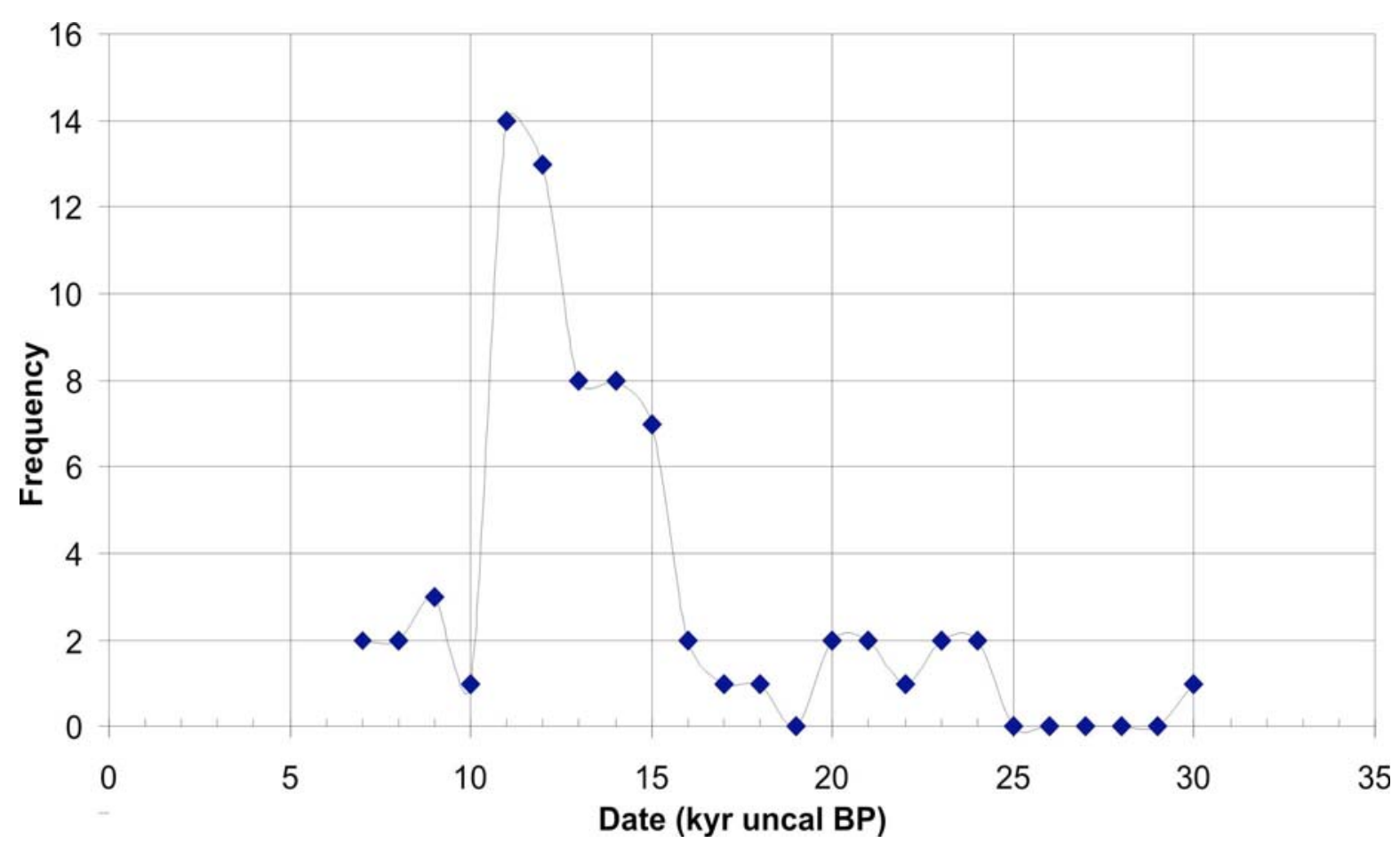

Fig. (13). Frequencies of radiocarbon dates of Khvalynian samples.

timated as $\sim 0.2 \mathrm{~m}$ per sec, the maximum discharge, as $40,000-50,000 \mathrm{~m}^{3}$ per $\mathrm{sec}$, and the total runoff as exceeding $1,000 \mathrm{~km}^{3}$ per annum, six times greater than that of the Volga River and exceeding thrice than that the Mississippi River. These estimates were based on the assumption that the sill remains stable at the level of $20 \mathrm{~m}$, yet the stream velocity would greatly increase if the depth reaches $30 \mathrm{~m}$. The latter suggestion is not in agreement with the fine grain size of the sediments. Such a contradiction may be explained by assuming a higher initial sill level, about $40 \mathrm{~m}$ asl or even more. In that case, the stream depth will not exceed a few meters and the water discharge will be much smaller, comparable to that of present-day Volga (c. $10,000 \mathrm{~m}^{3}$ per sec).

Table 4. Morphometric Characteristics of Caspian Basins

\begin{tabular}{|c|c|c|c|c|}
\hline Basins & $\begin{array}{c}\text { Mean } \\
\text { Sea-Level }\end{array}$ & $\begin{array}{c}\text { Basin } \\
\text { Area km² }\end{array}$ & $\begin{array}{c}\text { Basin } \\
\text { Volume } \mathbf{k m}^{\mathbf{3}}\end{array}$ & $\begin{array}{c}\text { Coastline } \\
\text { Length km }\end{array}$ \\
\hline \hline Atelian & -120 & 699,706 & 89,727 & 6,844 \\
\hline $\begin{array}{c}\text { Early } \\
\text { Khvalynian }\end{array}$ & +50 & 952,000 & 135,765 & 11,773 \\
\hline $\begin{array}{c}\text { Middle } \\
\text { Khvalynian }\end{array}$ & +22 & 83,800 & 106,656 & 10,112 \\
\hline $\begin{array}{c}\text { Late } \\
\text { Khvalynian }\end{array}$ & 0 & 699,706 & 896727 & 66844 \\
\hline $\begin{array}{c}\text { Present } \\
\text { Caspian Sea }\end{array}$ & -27 & 379,565 & 73,752 & 56767 \\
\hline
\end{tabular}

A transgression of this size necessitated an additional influx of about $70,000 \mathrm{~km}^{3}$ (not taking into account the evaporation and the Kumo-Manych spill out). The previous suggestions [11] that the transgression was fed by the water from the ice-dammed basins in the north are no longer valid.
As show the water balance calculations [29-31] an increase in the river runoff caused by the rise in precipitation in the Upper Volga catchment should be deemed as the main source of the water influx that had triggered the Khvalynian transgression. As show the pollen-based climatic reconstructions for the Allerød oscillation [37] the precipitation over the East European Plain and Western Siberia being lower than now considerably exceeded the LGM values. Earlier suggestions [14] of 'superfloods' caused by permafrost melting cannot be regarded as valid as it contradicts the observations showing a considerable stability of the Earth's 'cryogenic zone' [38, 39]. Shkatova [40] suggests that the melt snow was the main source of additional water. Regardless of its origins, the 'Manych-Kerch-Spillway' became part of a major waterway which included the Aral Sea, the Uzboi River the Khvalynian and the Black Sea basins [14] (Fig. 14).

Based on the reported materials, one may consider a considerably younger age (broadly contemporaneous with MOI 2) for Mousterian sites in the Caspian basin, which are usually associated with the populations of Neanderthal humans. The initial emergence of Mousterian industries in the Caspian basin as witnessed by the Volgograd site, might be brought in line with the Atelian regression, coeval with the LGM (25-18 ka). Their expansion was largely coeval with the Khvalynian transgression (Fig. 14).

Both the Caucasus and the Pamiro-Alay folded mountains were the areas of numerous Mousterian sites. The age of these sites in the Caucasus ranges from 250 to $29 \mathrm{ka} \mathrm{[41,}$ 42]. The complete skeleton of a Neanderthal child has been found at Teshik-Tash rock shelter in south-eastern Uzbekistan [43]. Its Neanderthal affiliation has been recently confirmed by mtDNA evidence, which also demonstrated its genetic affinity to European and Caucasian Neanderthals [44]. 


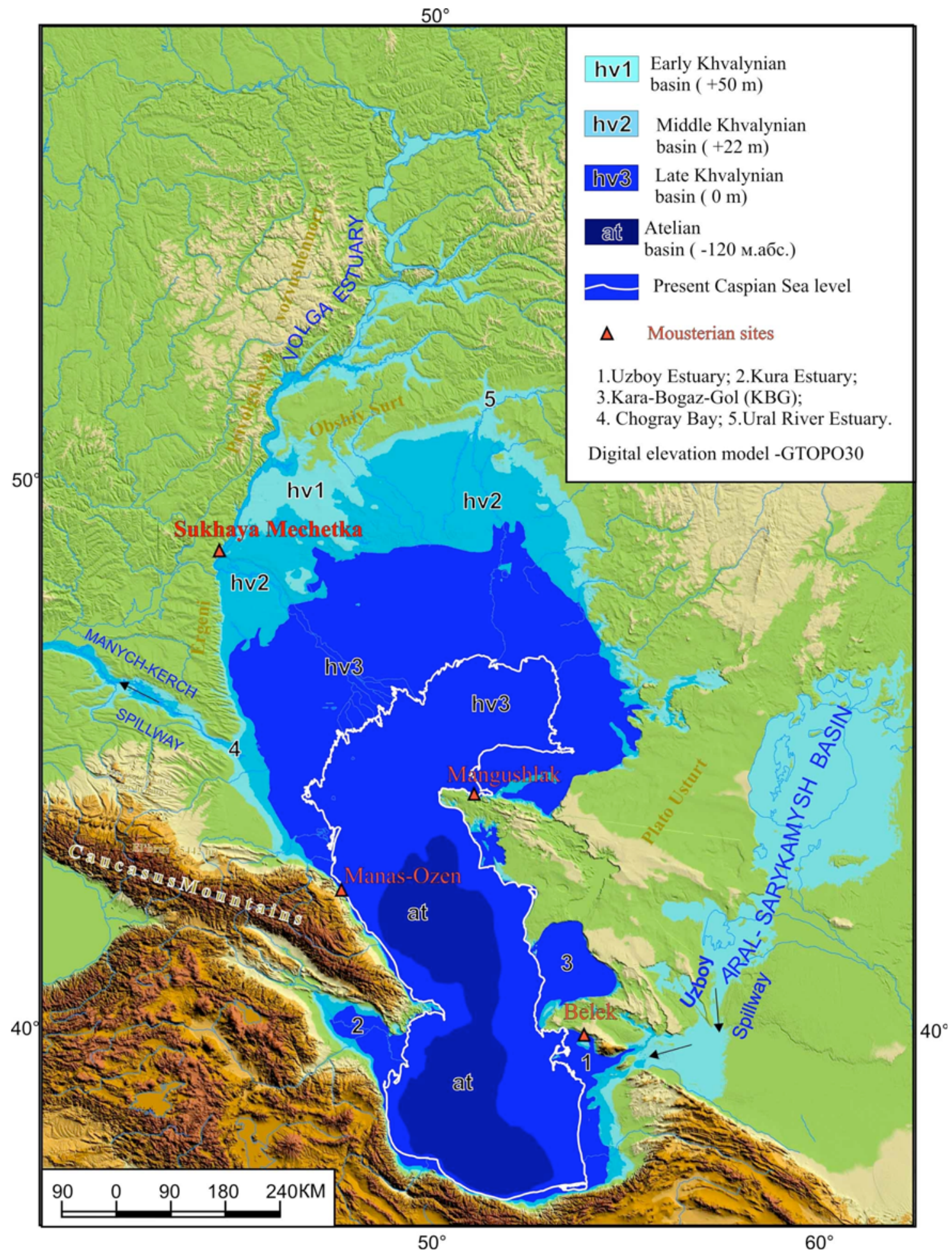

Fig. (14). The Khvalynian transgressions and Mousterian sites.

Significantly, there are very few authentic Upper Palaeolithic sites either in the central or eastern Caucasus or the Central Asia which age would exceed 12 ky. Obi-Rakhmat, the multi-layered Palaeolithic rock shelter in the western extension of the Tien Shan, yielded a series of C14 in the range of 54-56 to $19 \mathrm{ka}$ BP. Several writers [45-47] based on the high rate of laminar blanks and lame-based tools combined with the low percentage of Levallois forms in its stone inventory; consider the site as corresponding to the Middle- to Upper Palaeolithic transition. Vishnyatsky [48, 49] provides typological and statistical arguments demonstrating that this industry lays within the Mousterian technical variability.

One may reasonably suggest that during the course of the Khvalynian transgression specific environments arose in the Caspian basin that favoured a prolonged conservation of the Mousterian technique, and, possibly, a survival of Neanderthal populations. As possible factor one might mention the 
Caspian-Black Sea spillway across the Kumo-Manych Valley, which effectively isolated the Caucasian-Central-Asian area. The spread of Upper Palaeolithic technology in that area became possible only after the maximum of the Upper Khvalynian transgression, 12.5-12 ka BP.

\section{CONCLUSIONS}

- $\quad$ The Late Pleistocene fluctuations of the Caspian Sea levels were largely controlled by the Volga River discharge, which, in its turn, depended on the global climate dynamics.

- The Khvalynian transgressions were coeval with the mild Late Glacial episodes and the ice sheet recessions in the higher latitudes.

- $\quad$ The transgression proceeded in a quick alteration of successive sea-level fluctuations and in some cases had a catastrophic character.

- The 'Manych-Kerch-Spillway' linking the Caspian and Black sea basins Black Sea was in action during the peaks of the Khvalynian transgression.

- Specific environmental conditions which arose in the Caspian basin during the Late Glacial period contributed to the protracted conservation of Mousterian technologies, and, possibly, Neanderthal populations.

\section{ACKNOWLEDGEMENTS}

The writers would like to express their deep gratitude to IGCP 521 Programme "Black Sea-Mediterranean Corridor during last 30 ky: Sea level change and human adaptation" and to the Geological Society of London for sponsoring their participation at the IGCP 521 General Meetings in Gelendjik, Russia in 2007, where they had an opportunity to discuss the main topics of this paper. A special gratitude is due to anonymous reviewers whose thoughtful remarks have much improved the text.

\section{REFERENCES}

[1] Khain VE, Bogdanov NA. The Caspian megabasin: Tectonics and evolution. Geophys Res Abst 2005; 5: 203.

[2] Kroonenberg SB, Rusakov GV, Svitoch AA. The wandering of the Volga delta: A response to rapid Caspian sea-level change. Sediment Geol 1997; 107 (3-4): 189-209.

[3] Trubikhin VM. Paleomagnetizm i stratigrafiya akchagyl'skih otlozhenii v zapadnoi Turknenii (Palaeogagnetisn and stratigraphy of Akchagylian deposits in western Turkmenistan). Moscow: Nauka 1997.

[4] Rychagov GI. Kompleksnye issledovanija Kaspiiskogo morja (The complex studies of the Caspian Sea). Moscow: Moscow University Press 1997.

[5] Andrusov NI. O drevnih beregovyh linijah Kaspiiskogo morja (On the ancient Caspian sea shore lines) Ezhegodnik po geologii i mineralogii Rossii 1900; 4 (1-2): 3-10.

[6] Pravoslavlev PA. Kaspiiskie osadki v nizov'jah Volgi (The Caspian sediments on the Lower Volga). Izv central'nogo gidrometeobjuro 1926; 8: 1-54.

[7] Fedorov PV. Pleistotsen Ponto-Kaspiya (The Pontic-Caspian Pleistocene). Moscow: Nauka1978.

[8] Pravoslavlev PA. K geologii okrestnostei Baskunchakskogoi ozera (On the geology of the Baskunchak Lake surrounding area). Warsaw 1903.

[8] Golubyatnikov DV. Morskie in rechnye terrasy Dagestana (The Dagestan's marine and river terraces). Trudy Sov. sektsii INQUA; 1937: pp. 30-52.

[9] Fedorov PV. Stratigrafiya chetvertichnyh otlozhenii i istoriya razvitiya Kaspisskogo morya (Stratigraphy of Quaternary eosits and the history of the Caspian Sea). Tr Geologicheskogo Inst AN SSSR 1957; 10: 308 .

[10] Leont'yev OK, Maev EG, Rychagov GI. Geomorfologiya beregov i dna Kaspiiskogo morya (The geomorphology of the coasts and the floor of the Caspian Sea. Moscow: Moscow University Press 1977.

[11] Kvasov DD. The late quaternary history of large lakes and inland seas of Eastern Europe. Helsinki: Annales Academiae Scientiarum Fennicae Series A III. Geol Geogr 1975; 127: 71.

[12] Rychagov GI. Pleistocenovaya istoriya Kaspisskogo morya (The pleistocene history of the Caspian Sea ). ScD [Dissertation in Geography]. Moscow State University 1977.

[13] Svitoch AA. Kolebanija urovnja Kaspiiskogo morja v Pleistocene; klssifikacija i sistematicheskoe opisanie) (Oscillations of the Caspian Sea level in Pleistocene; classification and systematic description). In: Shcherbakov FA, Svitoch AA, Eds. Paleogeografija i geomorfologija Kaspiiskogo regiona v Pleistocene (Palaeogeography and geomorphology of the Caspian area in the Pleistocene). Moscow: Nauka 1991; pp. 5-100.

[14] Chepalyga AL. The late glacial flood in the Ponto-Caspian basin. In: Yanko-Hombach V, Gilbert AS, Panin N, Dolukhanov PM, Eds. The Black Sea flood question: Changes in coastline, climate and human settlement. Dordrecht: Springer 2007: pp. 119-48.

[15] Mayev EG, Chepalyga AL. Kaspiiskoe more (The Caspian sea). In: Velichko AA, Ed. Dinamika landshaftnyh komponentovi vnutrennih morskih basseinov Severnoi Evrazii za poslednie 130000 let (Dynamics of landscape components and inner marine basins of Northern Eurasia over the last 130,000 years. Moscow: Geos 2002; pp. 189-91.

[16] Chistyakova LA, Lavrushin YA. Suspensity vremeni poslednego oledeneniya na territprii Russkoi ravniny i prilezhashchih shel'fah (Suspensites of the last ice age on the Russian plain and adjoining shelves). Bulletin komissii po izucheniyu chetvertichnogo perioda 2004; 65: 36-44.

[17] Leont'yev OK, Kaplin PA, Rychagov GI. Novye dannye o chetvertichnoi istorii Kaspiisjogo morya (New evidence on Quaternary history of the Caspian Sea). In: Kaplin PA, Ed. Kompleksnye isseledovaniya Kaspiiskogo morya (Complex studies of the Caspian Sea), Moscow: Moscow University Press 1976; pp. 49-63.

[18] Kaplin PA, Leontjev OK, Il'ichev VA. K voprosu o vremeni hvalynskih trandgressii Kaspija po materialam radiouglerodnyh datirovok (To the question of the time of the Caspian Khvalynian transgressions on the evidence of radiocarbon dating). In: Kaplin PA, Ed. Paleogaografija i otloženija pleistocena yužnyh morei SSSR (Palaeogeography and pleistocene deposits of the southern seas of the USSR). Moscow: Nauka 1972; pp. 33-42.

[19] Leonov YG, Lavrushin YuA, Antipov MN, et al. Novye dannye o vozraste otlozhenii transgressivnoi fazy Ranne-Khvalynskoi transgressii Kaspiiskogo morya (New evidence on the age of Early Khvalynian transgression of the Caspian Sea). Doklady Akademii Nauk 2002; 386(2): 229-33.

[20] Dorofeyeva LA, Prilutskii RE, Shkatova VK. Dvoinoi karbonatnyi termometr kak instrument korrelyatsii i raschleneniya chetvertichnyh otlozhenii (The double carbonate thermometer as an instrument for correlation and subdivision of Quaternary sediments). Stratigrafiya, Geologicheskaya Korrelyatsiya 1996; 4(5): 105-110.

[21] Lavrentiev NV, Chepalyga AL. Morfometriya Kaspiiskogo basseina 16-10 tysyach let nazad (The morphometry of the Caspian basin 16-10 ka ago. In: (no editor) Vodnye resursy, ekologiya i gidrologicheskaya bezopasnost (Water resources, ecology and hydrological security), Moscow: Institute of Hydrological Problems 2007; pp. 70-6.

[22] Moskvitin AI. Pleistocen Nizhnego Povolzh'ja (The Pleistocene of the lower Volga). Tr Geologičeskogo Inst AN SSSR 1962; 64: 18798.

[23] Zamyatin SN. Stalingtadskaja paleoliticheskaja stojanka (The Stalingrad Palaeolithic site). Kratkie Soobščenija Inst Arheologii AN SSSR 1961; 82: 5-36.

[24] Praslov ND. Rannii paleolit Russkoi ravniny (Early palaeolithic of the Russian Plain). In: Boriskovsky PI, Ed. Paleolit SSSR - Arheologija SSSR. Moscow: Nauka 1984: pp. 107-24.

[25] Lyubin VP, Belyaeva EV. Rannyaya preistoriya Kavkaza (The early prehistory of Cucasus). ST. PETERSBURG: IIMK RAS 2006.

[26] Amirkhanov HA. Manas-ozen'skie must'erskie mestonahozhdeniya v Prikaspiiskom Dagestane (The Manas-Ozen Mousterian sites in the Dagestan's Caspian coastal area). In: Amirkhanov 
HA, Ed. Novoe v arheologii Severnogo Kavkaza (News in the archaeology of northern Caucasus). Moscow: Nauka 1986; pp. 1-7.

[27] Medoev AG. Geohronologiya paleolita Kazahstana (Geochronology of Kazakhstan's Palaeolithic). Alma-Ata: Nauka 1982.

[28] Dolukhanov PM. Raboty v Zapadnoi Turkmeni (Survey in Western Turkmenistan). In: Rybakov BA, Ed. Arheologicheskie otkrytiya 1976 goda (Archaeological discoveries of 1976). Moscow: Nauka 1977; pp. 551-2.

[29] Arpe K, Leroy SAG. The Caspian Sea level forced by the atmospheric circulation, as observed and modelled. Quat Int 2007; 173-4: 144-52.

[30] Kislov AV, Toporov PA. Modelirovanie izmenenii urovnei Chernogo i Kaspiiskogo morei pri razlichnyuh sostojanijah klimatov proshlogo (Modelling Black and Caspian seas levels in variable past climatic conditions). Vestnik Moskovskogo Universiteta, serija 5, Geografija 2006; Vol. 6: pp. 9-13.

[31] Kislov AV, Toporov PA. East European river runoff and Black Sea and Caspian Sea level changes as simulated within the Paleoclimate modelling intercomparison project. Quat Int 2007; 167-8: 408.

[32] Lowe JJ, Walker MJC. Quaternary environments, $2^{\text {nd }}$ ed. London: Longman 1984.

[33] Kaspar F, Kühl N, Cusbach U, Litt T. A model-data comparison of European temperatures in the Eemian interglacial. Geophys Res Lett 2005; 32: L11703, doi: 10.1029/2005GL022456.

[34] Svitoch AA. Morskoi pleistocen poberežii Rossii (The marine pleistocene of Russia's coasts). Moscow: Nauka 2003.

[35] Arslanov KA, Dolukhanov PM, Gei NA. Climate, Black Sea levels and human settlements in Caucasus Littoral 50,000 - 9,000 BP. Quat Int 2007; 167-168: 121-7.

[36] Coope GR. Fossil coleopteran assemblages as sensitive indicators of climatic changes during the Devensian (Last) cold stage. Phil Trans Roy Soc London. Ser B, Biol 1977; 280(972): 313-37.

[37] Velichko AA, Catto N, Drenova AN, Klimanov VA, Kremenetski $\mathrm{KV}$, Nechaev VP. Climate changes in East Europe and Siberia at the Late glacial-holocene transition. Quat Int 2002; 91(1): 75-99.

[38] Washburn AL. Permafrost features as evidence of climatic change. Earth-Sci Rev 1980; 12: 327-402.
[39] Solomatin VI. Geoekologiya i principy evolyucii geosistem Arktiki (Geoecology and principles of evolution of arctic geosystems). Krioisfera Zemli 2008; 12: 41-50.

[40] Shkatova VK. Palaeogeography of the late Pleistocene Caspian Basins: Geochronometry, palaeomagnetism, palaeotemperature, palaeosalinity and oxygene isopotes. IGCP 521-481 Joint Meeting and Field Trip Proceedings 2007; pp. 149-50.

[41] Golovanova LV, Hoffecker JF, Kharitonov VM, Romanova GP. Mezmaiskaya Cave: A Neanderthal occupation in the Northern Caucasus. Curr Anthropol 1999; 40: 77-86.

[42] Hidjrati NI, Kimblall LR, Koetje. Middle and late Pleistocene investigations of Myshtulagty Lagat (Weasel Cave) North Ossetia, Russia. Antiquity, Project Gallery 2003; 47(298). Available from: http://antiquity.ac.uk/projgall/hidjrati/index.html

[43] Okladnikov AP. Nahodka neandertal'tsa v Uzbekistane (The discovery of a Neanderthal in Uzbekistan). Vestnik drevnei istorii 1939; 1: 1-10.

[44] Krause J, Orlando L, Serre D, et al. Neanderthals in central Asia and Siberia. Nature 2007; 407: 902-4.

[45] Suleimanov RH. Statisticheskoe izuchenie grota Obi-Rakhmat (The statistical study of the Obi-Rakhmat Cave). Tashkent: Fan 1972.

[46] Derevianko AP, Krivoshapkin AI, Anoikin AA, et al. The initial upper Palaeolithic of Uzbekistan: The lithic industry of ObiRakhmat grotto (on the basis of materials recovered from strata 2 14). Arch Ethnograph Anthropol Euras 2001; 2 (4): 42-63.

[47] Krivoshapkin AI, Brantingham PJ. The lithic industry of ObiRakhmat Grotto, Uzbekistan. Actes du XIV Congres du UISPP. Oxford. BAR Int Ser 2004; 1240: 203-14.

[48] Vishnyatskii LB. Paleolit Srednei Azii i Kazahstana. (The Palaeolithic of Central Asia and Kazakhstan). St. Petersburg: Evropeiskii Dom 1996.

[49] Vishnyatsky LB. The Middle-Upper Paleolithic interface in Former Soviet Central Asia. In: Brantingham PJ, Kuhn SL, Kerry KW, Eds. The early upper Palaeolithic beyond Western Europe, Berkeley: University of California Press 2004; pp. 151-161.

() Dolukhanov et al.; Licensee Bentham Open.

This is an open access article licensed under the terms of the Creative Commons Attribution Non-Commercial License (http://creativecommons.org/licenses/by$\mathrm{nc} / 3.0 /$ ) which permits unrestricted, non-commercial use, distribution and reproduction in any medium, provided the work is properly cited. 